\title{
Pengaruh Price Cash Flow Ratio (PCFR) dan Price Sales Ratio (PSR) pada Return Saham (STUDI PADA PERUSAHAAN RITEL TAHUN 2015-2016)
}

\author{
Atik Tri Andari ${ }^{1}$ \\ Politeknik Negeri Malang PSDKU Kediri \\ Kediri \\ triatik1213@gmail.com
}

\author{
Yohan Bakhtiar $^{2}$ \\ Politeknik Negeri Malang PSDKU Kediri \\ Kediri \\ yohan_bakhtiar@yahoo.co.id
}

\begin{abstract}
ABSTRAK
Penelitian bertujuan untuk mengetahui apakah rasio pasar atau valuation ratio berpengaruh pada return saham. Emiten yang dipilih adalah emiten dari perusahaan ritel pada tahun 2015 sampai 2016. Penentuan sampel menggunakan metode purposive sampling. Analisis yang digunakan untuk melihat besarnya pengaruh rasio pasar dengan dimensi Price Cash Flow Ratio (PCFR) dan Price Sales Ratio (PSR) sebagai variabel independen terhadap return saham sebagai variabel dependen adalah analisis regresi linear berganda. Hasil penelitian ini menunjukkan bahwa Price Cash Flow Ratio (PCFR) berpengaruh terhadap return saham ditolak dan Price Sales Ratio (PSR) berpengaruh terhadap return saham diterima. Hasil penelitian dapat dikatakan bahwa investor tidak memandang Price Cash Flow Ratio (PCFR) dalam menilai return saham, akan tetapi melihat Price Sales Ratio (PSR) dalam menilai return saham.
\end{abstract}

Keywords : Rasio Pasar, Return Saham, Perusahaan Ritel

\section{Pendahuluan}

Perusahaan merupakan salah satu badan usaha yang melakukan kegiatan ekonomi, dimana usaha pendirian usaha adalah untuk menghasilkan barang atau jasa. Salah satu bentuk perusahaan di Indonesia adalah perusahaan ritel. Menurut Soliha (2008), industri ritel adalah industri yang menjual produk dan jasa pelayanan yang telah diberi nilai tambah untuk memenuhi kebutuhan pribadi, keluarga, kelompok, atau pemakai akhir. Perusahaan ritel memberikan kontribusi yang besar terhadap Produk Domestik Bruto (PDB) Indonesia, sehingga kontribusi ini meningkatkan kesejahteraan masyarakat. Hal ini didukung dengan adanya peningkatan perusahaan ritel di
Indonesia sebesar 9,5\% di tahun 2016. Berdasarkan data peningkatan perusahaan ritel ini diharapkan menambah daya tarik investor untuk menanam saham di perusahaan ini.

Daya tarik investor dalam menanam saham pada perusahaan ini dapat dilihat dari return saham yang akan diterima. Menurut Arista dan Astohar (2012), return saham merupakan kelebihan harga jual saham di atas harga belinya, dimana semakin tinggi harga jual saham di atas harga belinya, maka semakin tinggi pula return yang diperoleh investor. Apabila seorang investor menginginkan return yang tinggi maka, ia harus bersedia menanggung risiko lebih tinggi, demikian pula sebaliknya bila menginginkan return rendah, maka risiko yang akan 
ditanggung juga rendah. Hal ini berarti dalam memperjualbelikan saham investor menganalisis sahamnya, sehingga return yang diperoleh sesuai dengan harapannya.

Investor dapat melihat laporan keuangan perusahaan-perusahaan tersebut dalam melakukan penilaian dan analisa. Berdasarkan laporan keuangan tersebut dapat diketahui kinerja perusahaan dalam menjalankan kegiatan usaha dan kemampuan perusahaan dalam mendayagunakan aktivitas usahanya secara efisien dan efektif serta faktor di luar perusahaan ekonomi, politik, finansial dan lain-lain. Investor yang tidak berspekulasi tentu memperhitungkan dan menilai kinerja keuangan yang terdiri dari rasio-rasio keuangan dalam memilih saham. Analisis rasio keuangan dapat membantu para pelaku bisnis dan pihak pemerintah dalam mengevaluasi keadaan keuangan perusahaan masa lalu, sekarang dan memproyeksikan hasil atau laba yang akan datang (Juliana dan Sulardi, 2003). Jadi, rasio-rasio keuangan dapat dimanfaatkan untuk mengukur kinerja (performance) perusahaan, termasuk mengukur maupun memprediksi laba dan perkiraan laba di masa yang akan datang. Hal ini yang dapat menarik minat investor atau calon investor untuk menanamkan kelebihan uangnya di perusahaan tersebut melalui pasar modal, terutama dengan pembelian sekuritas seperti saham. Berdasarkan hal tersebut, maka dari itu penelitian ini bertujuan untuk mengetahui apakah rasio nilai pasar atau valuation ratio berpengaruh pada return saham.
Salah satu rasio keuangan yang dapat digunakan untuk menganalisa return saham adalah rasio nilai pasar. Menurut Widodo (2007) rasio pasar adalah rasio yang digunakan untuk mengukur nilai saham. Penelitian Meythi dan Mathilda (2012) menguji pengaruh rasio pasar, yaitu Price Earning Ratio (PER) dan Price to Book Value (PBV) terhadap return saham Indeks LQ45 pada tahun 20072009. Hasil penelitian adalah (1) Price Earnings Ratio (PER) berpengaruh negatif terhadap return saham, (2) Price to Book Value (PBV) tidak berpengaruh terhadap return saham, dan (3) Price Earnings Ratio (PER) dan Price to Book value (PBV) secara simultan tidak berpengaruh terhadap return saham. Penelitian Purba, Sinaga, dan Situmorang (2015) melakukan pengujian rasio pasar dengan variabel Price Earning Ratio (PER) terhadap return saham pada perusahaan food dan beverage yang terdaftar di Bursa Efek Indonesia. Hasil penelitian menunjukkan bahwa adanya pengaruh positif antara return dan PER, menunjukkan bahwa investor menggunakan data PER yang terdapat dalam laporan keuangan emiten sebagai alat analisis kesehatan suatu saham untuk memperoleh hasil (return) yang layak dari suatu investasi saham.

Beberapa rasio pasar yang berkaitan dengan return adalah Price Cash Flow Ratio (PCFR) dan Price Sales Ratio (PSR). Price cash flow ratio adalah rasio yang digunakan untuk menentukan harga saham suatu perusahaan yang dapat dicapai melalui aliran kas (Bragg, 2010). Berdasarkan rasio ini diharapkan investor dapat 
melihat return saham dari perspektif laporan arus kas. Hal ini dikarenakan investor lebih banyak menganalisis return saham berdasarkan laba perusahaan, sedangkan pada laba perusahaan mengandung transaksi non tunai dan depresiasi yang dapat dimanipulasi. Berdasarkan hal tersebut dapat dikatakan bahwa dengan adanya aliran kas, maka dapat memperlihatkan dasar proyeksi arus kas di masa yang akan datang yang dapat diukur menggunakan return saham (Alexander dan Detriana, 2013). Penelitian yang dilakukan oleh Penelitian Tumbel, Tinangon, dan Walandouw (2017) menunjukkan bahwa arus kas operasi berpengaruh positif, tetapi tidak signifikan terhadap return saham. Sedangkan, menurut penelitian Alexander dan Detriana (2013), aliran kas operasi, laba sisa, laba, dan market value added mempunyai pengaruh terhadap return saham. Penelitian Winarno (2013) menunjukkan bahwa operating cash flow (OCF) tidak berpengaruh signifikan positif terhadap return saham. Berdasarkan hal tersebut memperlihatkan bahwa hasil Price Cash Flow Ratio (PCFR) bagian dari rasio pasar tidak konsisten.

Price Sales Ratio (PSR) adalah rasio yang mengindikasikan pendapat investor perusahaan terhadap penjualan untuk menilai saham (Bragg, 2010). Price sales ratio mencerminkan kapitalisasi pasar dengan penjualan perusahaan dalam setahun. Rasio ini membandingkan antara harga saham dengan hasil penjualan bersih per saham. Hasil penjualan merupakan informasi yang lebih relevan dalam menilai keadaan perusahaan dibandingkan dengan pendapatan, karena pendapatan mengandung transaksi non tunai yang lebih mudah dimanipulasi. Investor menggunakan data Price Earning Ratio yang terdapat dalam laporan keuangan emiten sebagai alat analisis kesehatan suatu saham untuk memperoleh hasil (return) yang layak dari suatu investasi saham. Investor menganggap bahwa semakin besar Price Earning Ratio memungkinkan harga pasar dari setiap lembar saham akan semakin baik, dengan begitu investor akan memperoleh return dari perubahan harga saham (Purba, Sinaga, dan Situmorang, 2017). Berdasarkan hal tersebut memperlihatkan bahwa hasil Price Sales Ratio (PSR) bagian dari rasio pasar tidak konsisten.

Laporan keuangan yang baik yang dikeluarkan oleh perusahaan dapat dijadikan tanda bahwa perusahaan telah beroperasi secara baik (Sunardi, 2010). Kemudian, investor akan melihat sinyal untuk pengambilan keputusan itu dapat melalui laporan keuangan. Sinyal bagi investor ini dapat memberikan reaksi, sehingga reaksi pasar ini dapat dilihat melalui return saham. Return saham yang semakin besar dapat dianalisis melalui laporan keuangan yang baik. Hal ini sesuai dengan Teori Signal bahwa laporan keuangan yang baik adalah yang terlihat bahwa operasi weusahaan berjalan dengan baik. Laporan ini dapat dilihat berdasarkan rasio-rasio keuangan perusahaan. Salah satu rasio keuangan yang dapat digunakan untuk menganalisa return saham adalah rasio pasar atau valuation ratio. Hal ini dikarenakan 
rasio nilai pasar (valuation ratio) mencerminkan arus kas perusahaan, sehingga dapat dijadikan informasi alternatif dalam menilai kinerja dan prospek perusahaan, pada saat laba mempunyai peluang yang besar untuk tersentuh praktek manipulasi.

Penjelasan pada paragrafparagraf sebelumnya menunjukkan bahwa penelitian terkait rasio pasar (valuation ratio) terhadap return saham perlu dilakukan dikarenakan beberapa alasan. Pertama, adanya fenomena bahwa perusahaan ritel di Indonesia mengalami peningkatan hingga 9,5\% di tahun 2016. Kedua, penelitian sebelumnya mengalami ketidakkonsistenan hasil terkait rasio pasar khususnya Price Cash Flow Ratio (PCFR) dan Price Cash Ratio (PSR) terhadap return saham. oleh karena itu, penelitian ini menguji ulang mengenai rasio pasar terhadap return saham, sehingga hasil dari penelitian ini diharapkan dapat memberikan referensi baru bagi akademisi dan investor terkait analisis rasio pasar terhadap return saham.

\section{Metode Penelitian}

Penelitian ini merupakan penelitian kuantitatif. Menurut Arikunto (2006), penelitian kuantitatif dituntut menggunakan angka dari mengumpulkan data, penafsiran terhadap data tersebut, serta penampilan hasilnya. Penelitian ini ditujukan untuk meneliti rasio penilaian (valuation ratio) dengan dimensi Price Cash Flow Ratio (PCFR) dan Price Sales Ratio (PSR). Jenis data yang digunakan yaitu data sekunder. Data sekunder penelitian ini adalah data keuangan yang diambil dari laporan keuangan perusahaan yang listing di Bursa Efek Indonesia.

Populasi pada penelitian ini adalah laporan keuangan perusahaan ritel yang listing di Bursa Efek Indonesia (BEI) periode 2015 sampai 2016. Penentuan sampel menggunakan metode purposive sampling, yaitu penentuan sampel dari populasi yang ada berdasarkan kriteria. Kriteria yang dipakai dalam penentuan sampel adalah sebagai berikut :

1. Perusahaan ritel telah terdaftar di BEI di tahun 2014 sampai 2017, sehingga data tersedia untuk menghitung variabel-variabel penelitian.

2. Perusahaan ritel yang tidak keluar dari BEI periode tahun 2014 sampai 2017.

3. Perusahaan ritel menyajikan data laporan keuangan secara lengkap mulai tahun 2014 sampai 2017.

Teknik analisis untuk melihat besarnya pengaruh rasio pasar dengan dimensi Price Cash Flow Ratio (PCFR) dan Price Sales Ratio (PSR) sebagai variabel independen terhadap return saham sebagai variabel dependen, maka digunakan analisis regresi linier berganda.

\section{Hasil Penelitian \\ Deskripsi Sampel Penelitian}

Populasi yang dipilih dalam penelitian ini adalah perusahaan ritel yang konsisten terdaftar di Bursa Efek Indonesia (BEI) tahun 2014 sampai 2017. Berikut adalah rincian jumlah sampel akhir berdasarkan kriteria pengambilan sampel. 


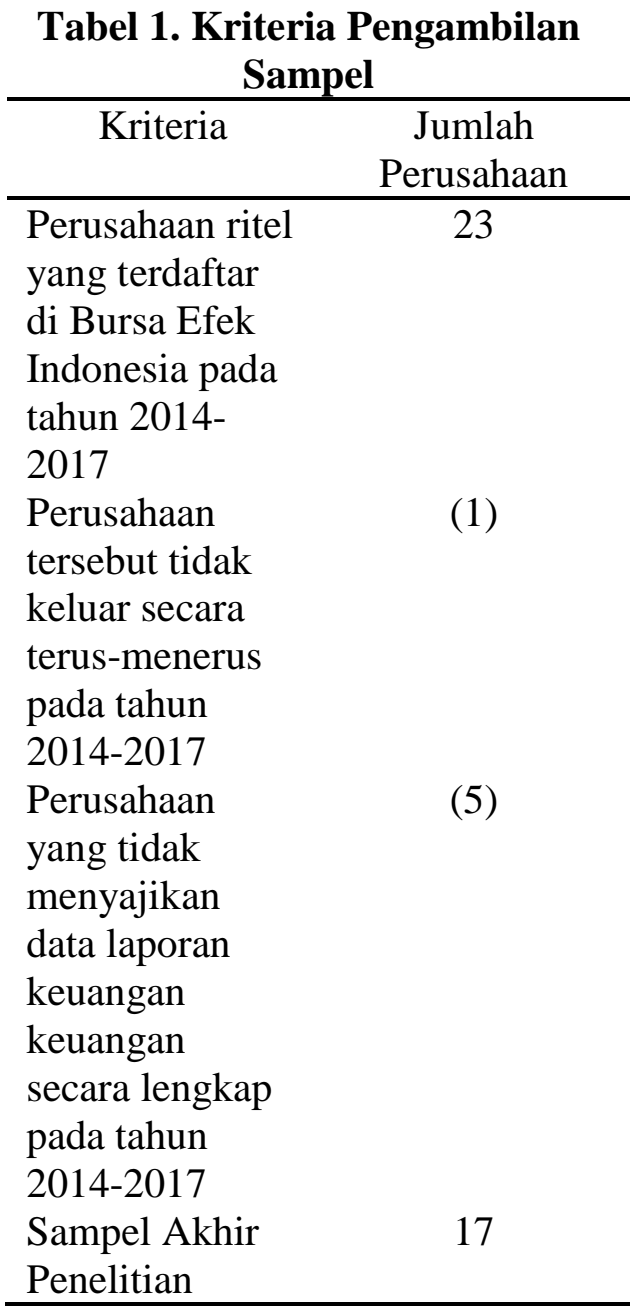

\section{Analisis Data}

Hasil statistik deskriptif memberikan suatu gambaran suatu data. Data yang digunakan untuk menguji hipotesis, yaitu Price Cash Flow Ratio (PCFR), Price Sales Ratio (PSR), dan return saham. Hasil analisis deskriptif data perusahaan adalah sebagai berikut:

\section{Tabel 2. Hasil Statistik Deskriptif Variabel Penelitian}

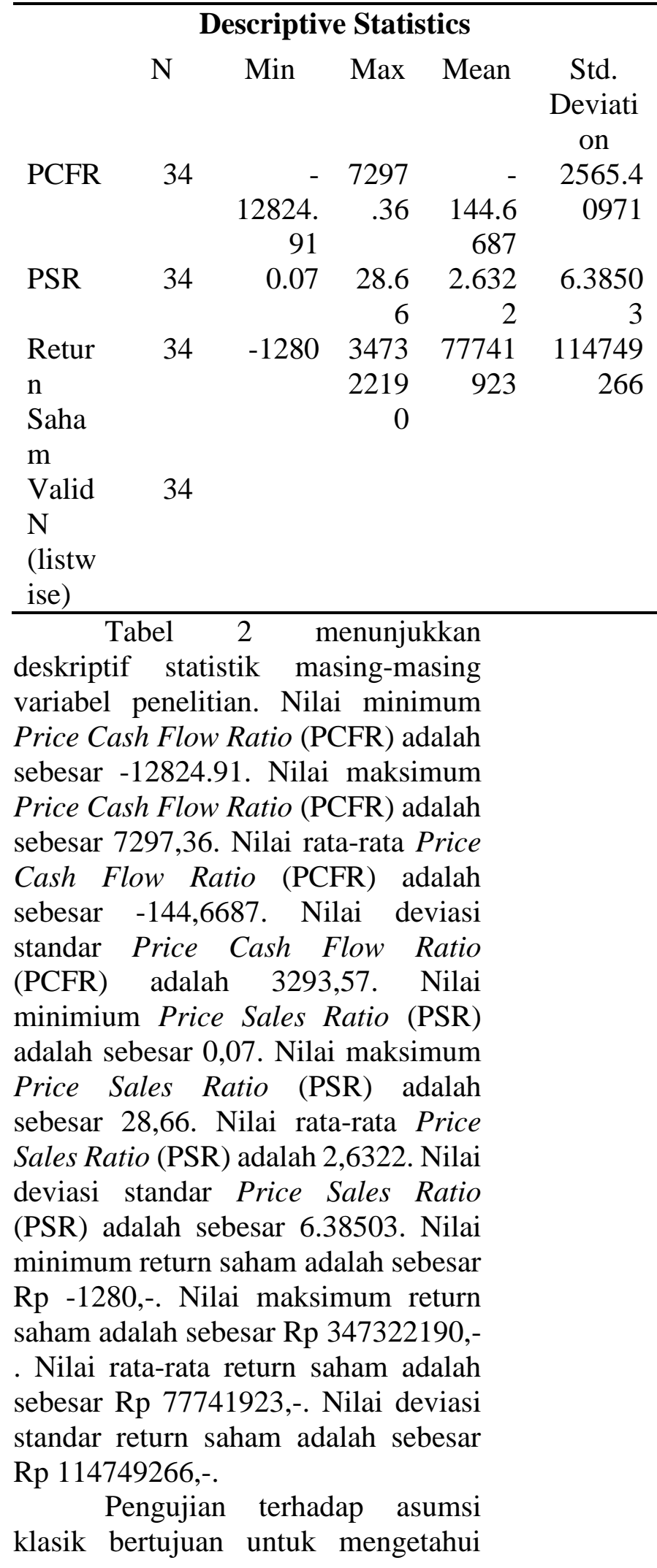


apakah suatu model regresi tersebut baik atau tidak jika digunakan untuk melakukan penaksiran. Suatu model dikatakan baik apabila bersifat BLUE (Best Linear Unbiased Estimator), yaitu memenuhi asumsi klasik atau terhindar dari masalah-masalah uji normalitas, multikoliniearitas, autokorelasi, heteroskedastisitas.

a. Uji Normalitas

Pada umumnya hasil uji normalitas dapat berupa analisis grafik yaitu dengan menggunakan grafik normal plot. Berikur adalah hasil uji normalitas. Gambar 1 berikut menunjukkan bahwa grafik memberikan pola distribusi yang mendekati normal, pada grafik terlihat titik-titik menyebar di sekitar garis diagonal serta penyebarannya ada di sekitar garis diagonal.

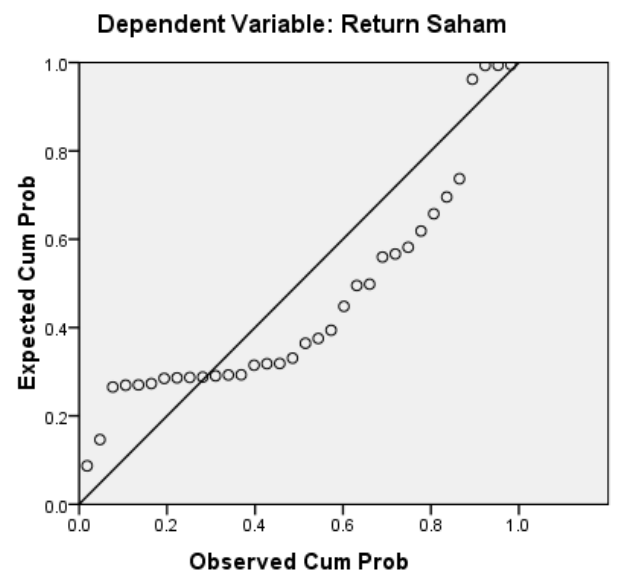

\section{Gambar 1. Hasil Uji Normalitas}

b. Uji multikolinieritas regresi yang baik seharusnya tidak terjadi korelasi di antara variabel independen. Tabel 3 berikut menjelaskan hasil multikolinieritas dari model regresi:

Tabel 3. Hasil Uji Multikolinieritas Coefficients $^{\mathrm{a}}$

\begin{tabular}{|c|c|c|c|c|c|}
\hline \multirow{2}{*}{\multicolumn{2}{|c|}{ Model }} & \multicolumn{2}{|c|}{$\begin{array}{l}\text { Unstandardiz } \\
\text { ed } \\
\text { Coefficients }\end{array}$} & \multicolumn{2}{|c|}{$\begin{array}{l}\text { Collinearity } \\
\text { Statistics }\end{array}$} \\
\hline & & B & $\begin{array}{l}\text { Std. } \\
\text { Error }\end{array}$ & $\begin{array}{c}\text { Toleranc } \\
\mathrm{e}\end{array}$ & VIF \\
\hline 1 & $\begin{array}{l}\text { (Cons } \\
\operatorname{tant})\end{array}$ & $\begin{array}{l}5.37 \\
0 \mathrm{E} 7\end{array}$ & $\begin{array}{r}1.896 \\
\text { E7 }\end{array}$ & & \\
\hline & PCFR & $\begin{array}{r}692 . \\
788\end{array}$ & $\begin{array}{r}6910 . \\
374\end{array}$ & .998 & 1.002 \\
\hline & PSR & $\begin{array}{l}917 \\
077\end{array}$ & $\begin{array}{r}27764 \\
85\end{array}$ & .998 & 1.002 \\
\hline
\end{tabular}

a. Dependent Variable: Return Saham

Berdasarkan Tabel 3, maka hasil perhitungan nilai tolerance menunjukkan tidak ada variabel independen yang memiliki nilai Variance Inflation Factor (VIF) menunjukkan hal yang sama dimana tidak ada satu variabel independen yang memiliki nilai VIF lebih dari 10. Jadi dapat disimpulkan bahwa tidak ada multikolinieritas antar variabel independen dalam model regresi.

c. Uji Autokorelasi

Pengujian autokorelasi dapat dilakukan dengan melihat nilai output SPSS untuk Durbin-Watson (DW). Tabel 4 berikut merupakan nilai Durbin-Watson untuk uji autokorelasi.

Tabel 4. Hasil Uji Autokorelasi

\begin{tabular}{lrrr}
\hline & \multicolumn{3}{c}{ Model Summary } \\
Model & \multicolumn{1}{c}{$\mathrm{R}$} & R Square & Durbin- \\
& & & Watson \\
1 & $.511^{\mathrm{a}}$ & .261 & 1.259
\end{tabular}

a. Predictors: (Constant), PSR, PCFR

Berdasarkan Tabel 4 diperoleh nilai Durbin-Watson (DW) sebesar 1,259. Dilihat pada tabel Durbin Watson dengan tingkat signifikansi $5 \%$, untuk $\mathrm{n}$ yang berjumlah 34 
perusahaan sampel dengan 2 variabel bebas $\left(\mathrm{k}^{\prime}=2\right)$ diperoleh nilai $\mathrm{dl}=$ 1,333 dan $\mathrm{dU}=1,580$. Rentang Durbin-Watson untuk tingkat signifikansi $5 \%$ yaitu $0<1,259<$ 1,333, maka nilai Durbin-Watson (d) sebesar 1,259 berada diantara nilai 0 dan 1,333. Hal ini dapat diperoleh kesimpulan bahwa model regresi tersebut sudah bebas dari masalah autokorelasi.

d. Uji Heteroskedastisitas

Model regresi yang baik adalah homoskedastisitas atau tidak terjadi heterokedastisitas. Pendeteksiaan terhadap ada tidaknya heterokedastisitas dapat dilihat melalui gambar grafik scatterplot. Grafik scatterplot untuk uji heterokedastisitas adalah pada Gambar 2 berikut.

Scatterplot

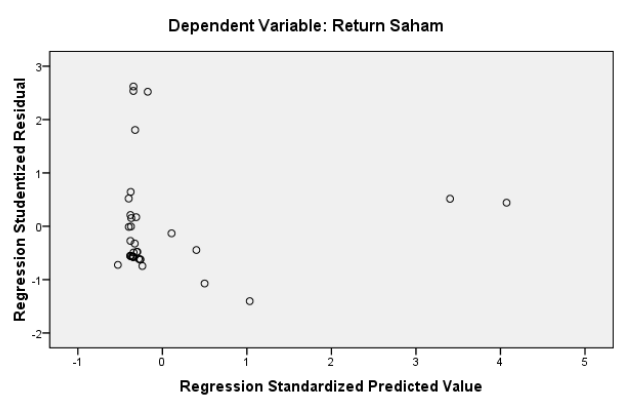

Gambar 2. Grafik Scatterplot

\section{Hasil Uji Hipotesis}

a. Uji Koefisien Determinan

Koefisien determinasi berguna untuk mengukur seberapa jauh kemampuan model dalam menerangkan variasi variabel independen. Penjelasan hasil koefisien determinasi dari model regresi sesuai dengan Tabel 5 berikut.

Tabel 5. Koefisien Determinasi

\section{Model Summary}

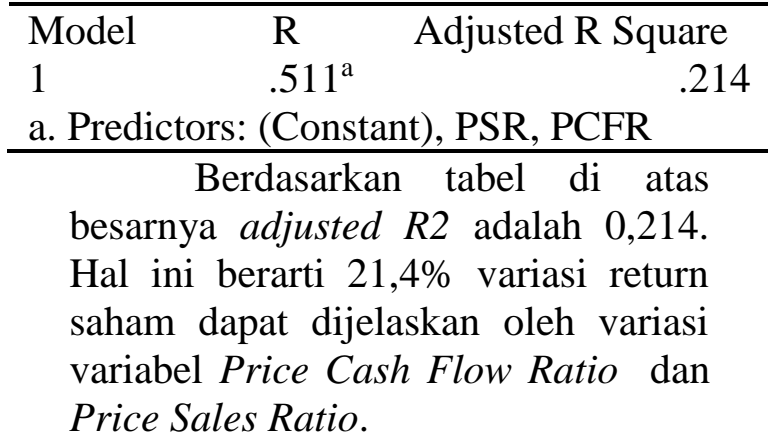

b. Uji Statistik t

Uji statistik $\mathrm{t}$ dilakukan untuk menunjukkan seberapa jauh pengaruh satu variabel independen secara individual dalam menerangkan variasi variabel dependen. Hasil uji statistik t dijelaskan dalam Tabel 6 berikut

Tabel 6. Uji Statistik t

\begin{tabular}{llrr}
\hline \multirow{2}{*}{ Model } & \multicolumn{2}{c}{ Coefficients $^{\mathbf{a}}$} & \multicolumn{1}{c}{ Sig. } \\
& & & \\
1 & (Constant & 2.832 & .008 \\
& ) & & \\
& PCFR & .100 & .921 \\
& PSR & 3.303 & .002
\end{tabular}

a. Dependent Variable: Return Saham

Berdasarkan tabel di atas, dapat diketahui pengaruh secara parsial dari variabel Price Cash Flow Ratio (PCFR) dan Price Sales Ratio (PSR) terhadap return saham. Berdasarkan hasil uji statistik $t$ di atas, variabel independen untuk PCFR yang dimasukkan ke dalam model regresi dengan tingkat signifikansi sebesar 5\% adalah tidak signifikan. Hal ini dikarenakan nilai signifikansi 0,921 lebih besar dari 0,05. Kemudian untuk variabel independen PSR signifikan pada tingkat signifikansi 5\%, dikarenakan nilai signifikansinya sebesar 0,002 lebih kecil dari 0,05. Hal ini dapat disimpulkan bahwa secara parsial variabel return saham tidak dapat dipengaruhi oleh Price Cash 
informasi mengenai price cash flow ratio sebagai tolak ukur dalam menilai return saham untuk kepentingan investasi mereka.

Berdasarkan hasil regresi dapat diketahui bahwa hipotesis kedua yang menyatakan bahwa price sales ratio berpengaruh terhadap return saham diterima. Hal ini dapat dilihat dari price sales ratio nilai t-hitung sebesar 3,303 lebih besar dibandingkan dengan nilai t-tabel yaitu $1,691(\mathrm{df}=$ 34 ), serta nilai signifikansi sebesar 0,002 lebih kecil dari tingkat signifikansi 5\%. Price Sales Ratio (PSR) adalah rasio yang mengindikasikan pendapat investor perusahaan terhadap penjualan untuk menilai saham (Bragg, 2010). Sama seperti price earning ratio, price sales ratio merefleksikan berapa banyak yang harus dibayarkan investor untuk setiap penjualan perusahaan. Price sales ratio merupakan salah satu indikator yang digunakan investor dalam pengambilan keputusan investasi dikarenakan pada rasio ini terlihat seberapa banyak penjualan yang dihasilkan dari modal yang mereka investasikan. Selain itu pada rasio ini terlihat pwnjualan perusahaan sebenarnya tanpa berdampak pada penyesuaian.

Hasil penelitian ini konsisten dengan penelitian Purba, Sinaga, dan Situmorang (2017) yang menunjukkan bahwa pengaruh Price Earning Ratio cukup signifikan dan positif terhadap return saham. Hal ini berarti perusahaan yang telah dipandang investor memiliki price sales ratio tinggi memiliki return saham lebih tinggi dan perusahaan yang memiliki price sales ratio yang rendah memiliki return saham yang rendah. Dapat disimpulkan bahwa investor memandang informasi mengenai price sales ratio sebagai tolak ukur dalam menilai return saham untuk kepentingan investasi mereka.

\section{SIMPULAN}

Penelitian ini bertujuan untuk mengetahui apakah rasio nilai pasar atau valuation ratio berpengaruh pada return saham. Rasio nilai pasar di ukur dengan price cash flow ratio dan price sales ratio. Sampel yang digunakan di dalam penelitian ini sebanyak 17 perusahaan ritel dari tahun 2014 2017. Hipotesis pertama yang menyatakan bahwa price cash flow ratio berpengaruh terhadap return saham ditolak. Hal ini berarti perusahaan yang dipandang investor memiliki price cash flow ratio tinggi justru return sahamnya lebih rendah dan perusahaan yang memiliki price cash flow ratio yang rendah memiliki return saham yang tinggi. Hipotesis kedua yang menyatakan bahwa adanya price sales ratio berpengaruh terhadap return saham diterima. Perusahaan yang dipandang investor memiliki price sales ratio tinggi memiliki return sahamnya lebih tinggi dan perusahaan yang memiliki price sales ratio yang rendah memiliki return saham yang rendah. Hasil penelitian ini menunjukkan bahwa investor tidak memandang price cash flow ratio dalam menilai return saham, akan tetapi investor memandang price sales ratio dalam menilai return saham.

Penelitian ini diharapkan
mampu memberikan tambahan mengenai teori di bidang akuntansi, khususnya di bidang akuntansi 
keuangan dan pasar modal. Selain itu, penelitian ini diharapkan mampu dijadikan perbandingan dan tambahan referensi bagi peneliti selanjutnya mengenai obyek yang sejenis dan sebagai acuan untuk mendalami mengenai rasio nilai pasar (valuation ratio) dan return saham. Terakhir, hasil penelitian ini diharapkan akan memberi masukan bagi perusahaan, baik yang terdaftar di bursa maupun yang tidak, terkait rasio nilai pasar (valuation ratio) dan return saham. Hasil penelitian diharapkan juga dapat memberikan informasi yang berguna bagi investor, kreditur dan lainnya dalam memahami kandungan informasi akuntansi sebagai pertimbangan pengambilan keputusan. Penelitian ini memiliki beberapa keterbatasan. Keterbatasanketerbatasan tersebut antara lain:

1. Penelitian ini hanya menggunakan perusahaan ritel saja, sehingga hasil penelitian ini tidak bisa digeneralisasi untuk industri keuangan.

2. Penelitian ini tidak memasukkan atribut rasio pasar yang lain, seperti price earnings ratio, dan price to book value ratio

\section{DAFTAR PUSTAKA}

Alexander, Nico dan Destriana, Nicken. 2013. Pengaruh Kiinerja Keuangan Terhadap Return Saham. Jurnal Bisnis dan Akuntansi Vol 15, No. 2, Desember, Hlm. 123-132
Arikunto, S. 2006. Prosedur Penelitian Suatu

Pendekatan Praktik. Rineka Cipta: Jakarta

Arista, Desy dan Astohar. 2012. Analisis Faktor-faktor yang Mempengaruhi Return Saham (Kasus pada Perusahaan Manufaktur yang Go Public di BEI Periode Tahun 2003-2009). Jurnal Ilmu Manajemen dan Akuntansi Terapan Vol. 3 No.1

Bragg, Steven M. 2010. Business Ratios and Formulas a Comprehensive Guide. John Wiley \& Sons Inc: United States of America

Ghozali, I. 2012. Aplikasi Analisis Multivariate dengan Program SPSS. Edisi 3. Cetakan 5. Badan Penerbit Universitas Diponegoro. Semarang.

Juliana, Roma Uly dan Sulardi. 2003. Manfaat Rasio Keuangan Dalam Memprediksi Perubahan Laba Perusahaan Manufaktur. Jurnal Bisnis \& Manajemen, Vol. , No. 2

Meythi, dan Mathilda, Mariana. 2012. Pengaruh Price Earnings Ratio dan Price to Book Value terhadap Return Saham Indeks LQ 45 (Perioda 2007-2009). Jurnal Akuntansi Vol. 4 No. 1 Mei, Hal 1-21. 
Muizudin. 2015. Analisis Rasio Keuangan Sebagai Alat Untuk Menilai Kinerja Keuangan. Jurnal Ilmu dan Riset Manajemen Volume 4, No. 5, Mei, hlm.1-18.

Purba, Imelda R., Sinaga, Ria V., dan Situmorang, Zakarias. 2015. Analisis Price Earning Ratio (PER) Terhadap Return Saham Pada Perusahaan Food dan Beverage. Conference Paper September 2015. https://www.researchgate.n et/publication/318796318 diakses pada tanggal $20 \mathrm{Mei}$ 2018 pukul 12.15 .

Soliha, Euis. 2008. Analisis Industri Ritel di Indonesia. Jurnal Bisnis dan Ekonomi, Vol.15, No. 2, Hlm: 128142

Soesetio, Yuli dan Anam, Anam, M. Khoirul. Pengaruh Rasio Arus Kas Terhadap Return Saham Perusahaan Manufaktur Kelompok Basic Industry and Chemicals (Tahun 20082009). Modernisasi, Vol. 7 No. 1 Februari, Hal. 24-39
Sunardi, Harjono. 2010. Pengaruh Penilaian Kinerja dengan ROI dan EVA terhadap Return Saham pada Perusahaan yang tergabung dalam Indeks LQ45 di Bursa Efek Indonesia. Jurnal Akuntansi, Vol. 2, No. 1, Hal. 70-92

Tumbel, Gilbert A., Tinangon, Jantje, dan Walandouw, Stanley K. 2017. Pengaruh Laba Akuntansi dan Arus Kas Operasi Terhadap Return Saham Pada Perusahaan Manufaktur Sektor Industri Barang Konsumsi Yang Terdaftar di Bursa Efek Indonesia. Jurnal EMBA Vol 5 No. 1 Maret 2017, Hal. 173-183.

Widodo, Saniman. 2007. Analisis Pengaruh Rasio Aktivitas, Rasio Profatibilitas dan Rasio Pasar terhadap Return Saham Syariah dalam Kelompok Jakarta Islamic Index (JII) Tahun 20032005. Tesis. Universitas Diponegoro 